\title{
Лідерські якості як важливий фактор успішності професійної діяльності фахівців соціономічних професій
}

У статті проаналізовано сучасні наукові дані, які накопичено в області психології лідерства, з точки зору впливу иього феномену на успішність діяльності фахівиів соиіономічних професій. Лідерство розглядається як здатність вести за собою, керувати чи управляти групою/організаиією. Показано, щяо в сучасному суспільстві різні ситуаиії вимагають різних рис лідерства і різних форм поведінки. На основі аналізу досліджень про проблеми лідерства визначено певні вимоги до сочіальної ролі лідера в намому суспільстві, зокрема: лідер повинен мати здібність брати керування на себе; бути гнучким в управлінні людьми; вміти створювати в групі консенсус, атмосферу співробітництва, відношення взаємної довірі, поваги, взаєморозуміння, прихильності до однієї ідеї; вміти турбуватися як про людей, так і про рішення завдання; бути стійким до стресу, енергійним і наполегливим.

Ключові слова: лідер, лідерство, моделі лідерства, успішність діяльності фахівиів соціономічних професій, професійний досвід, компетентність, комунікативна компетентність.

Постановка проблеми. Сучасні соціально-економічні процеси в нашому суспільстві пред'являють підвищені вимоги до якостей фахівців таких важливих областей практики, як управлінська, науково-педагогічна, педагогічна, юридична, медична, психологічна тощо. Серед якостей, які забезпечують успішність роботи з людьми, є лідерські якості.

Аналіз останніх досліджень 3 проблеми. В багатьох психологічних дослідженнях доводиться те, що лідерство - це один iз важливих факторів в досягненні успіху груп і організацій $[1 ; 5 ; 6]$. Зокрема, ефективне лідерство може компенсувати багато різних недоліків і «дефіцитів» в процесах функціонування груп. Виходячи із такої високої значущості, лідерські якості все частіше стають об'єктом саморозвитку [2; 3; 4].

Мета даної роботи: проаналізувати сучасні наукові дані, які накопичено в області психології лідерства, з точки зору впливу цього феномену на успішність діяльності фахівців соціономічних професій.

Виклад основного матеріалу дослідження. В сучасній психології лідерство розглядається переважно: як певний набір вроджених якостей, особливості стилю поведінки, наслідок, головним чином, тієї ситуації, в який опинився лідер $[4 ; 5]$.
В нашому дослідженні ми розуміємо «лідерство» як здатність вести за собою, керувати чи управляти групою/організацією. Звернімо увагу на те, що більшість визначень лідерства включає три компонента: вплив, групу і ціль. Більш точніше: лідери - це люди, які впливають на поведінку інших (учні, підлеглі, колеги, послідовники тощо); лідерство, зазвичай, досліджується в контексті груп (наприклад, професійних колективів, учнівських класів, спортивних команд); групова ціль, яка повинна бути досягнута — важлива сторона лідерства [3; 6]. Узагальнюючи ці три компонента, можна сказати, що лідерство - це процес, при якому людина впливає на інших членів групи заради досягнення мети.

Важливим питанням $є$ визначення тих якостей, які притаманні успішним лідерам. Як відомо, виокремлюють такі основні варіанти лідерських стилів: авторитарний, попустливий, врівноважений, демократичний, командний тощо [4]. Багаточисленні дослідження довели, що ефективність конкретного, окремо взятого стилю лідерства в значній мірі залежить від ситуаційних факторів. Психологами був зроблений висновок: хоча і в деяких випадках один стиль може бути кращим за інший, не існує єдиного стилю лідерства, який підхо- 
дить до всіх ситуацій: для різних ситуацій існує свій оптимальний стиль [5]. Це пояснюється тим фактом, що в сучасному суспільстві люди можуть бути лідерами в одних ситуаціях, а підлеглі (послідовники) - в інших. Тобто, якщо кожний може бути і лідером і підлеглим, різниці в рисах особистості в цих двох ролях не буде. Теж саме стосується і ефективності лідерства: в одних ситуаціях можна бути прекрасним лідером, а в інших - не таким успішним. Інакше кажучи, різні ситуації вимагають різних рис лідерства і форм поведінки.

Усвідомлення важливості ситуаційних факторів привело до виникнення ситуаційних теорій, в яких намагалися виділити умови, при яких конкретний стиль лідерства міг бути найбільш ефективним [5; 6]. При вивченні стилів лідерства характерним для дослідників $\epsilon$ відсутність згоди у відношенні кінцевого набору ситуаційних змінних. Теоретики погоджуються у визнанні важливої ролі ситуаційних змінних для аналізу систематичних взаємозв'язків між стилем і критеріями ефективності лідерства. Причини цього визнання - багаточисельні дослідження в різних організаціях, які продемонстрували відсутність стилю лідерства, який би був ефективним в усіх ситуаціях [6]. Тобто, у відношенні до конкретного завдання лідер повинен враховувати ситуаційні фактори: а) які впливають на якість самого рішення; б) які впливають на виконання підлеглими цього рішення) і обрати той чи інший стиль прийняття рішення.

Домінуючі теорії і пов'язані з ними дослідження в період 1940-1960-х років характеризувалися трьома відмінними рисами: 1) ці теорії грунтувалися на переконанні, що найкращим методом лідерства $\epsilon$ центрований на працівникові чи орієнтований на відношення підхід; 2) вони концентрували свої дослідницькі зусилля на таких міжособистісних змінних, як лідерські аттитюди, поведінка та мотивація; 3) вони відводили другорядну роль таким когнітивним змінним, як лідерський інтелект, продуктивність в рішенні виробничих завдань i робочі знання [4]. Ця остання точка зору (що когнітивні змінні не грають суттєвої ролі) не розділялися практиками, які повинні були прогнозувати майбутню продуктивність менеджерів чи здійснювати рекомендації по просуванню і розстановці керівників.

На протязі цього періоду дослідники систематично вивчали форми поведінки, які асоціювалися 3 ефективним лідерством. Таке вивчення призвело до виділення, наприклад, двох важливих «поведінкових факторів». Один фактор, який отримав назву «увага», включав в себе соціоемоційні, експресивні форми поведінки, які пов'язані $з$ проявом інтересу і турботливої участі до думок, почуттів та благополуччю підлеглих. Другий фактор - «структурування» — включав в себе розподілення ролей і завдань серед членів групи, установку стандартів, оцінку виконання і фокусування на виробничих завданнях [1].

Нагадаємо, що ефективні і менш ефективні лідери вивчалися і в рамках теорії лідерських якостей. Тож, що ж таке «успішне лідерство»? Зрозуміло, що для ефективної діяльності необхідна висока компетентність і набір певних функціональних вмінь. Але існують дослідження, які вказують на те, що дійсне лідерство - це просто здібність здійснювати вплив. Так, Л. Холлон включає в нього: вміння заставити групу зосередитися на загальній цілі; вміння створити в групі консенсус; розвинути у членів групи відданість загальній справі і мотивацію до досягнень; залучити людей до сумісної роботи і спонукати їх робити те, що необхідно організації (групі, команді) тому, що вони самі прийшли до рішення, що хочуть це робити $[6 ; 5]$.

Результати дослідження особливостей поведінки успішних керівників, проведеного американськими вченими Дж. Канджемі і К. Дж. Ковальські, поглиблюють уявлення про якості успішних лідерів. Зокрема, цими авторами було виділено наступні характеристики: особливості мислення (здібність до екстраполяції; здібність до розробки декількох проблем одночасно; стійкість в ситуації невизначеності; розуміння, розвинута інтуїція здібність схоп- 
лювати суть справи інтуїтивно і швидко); вміння справлятися з агресією (здібність брати керування на себе; наполегливість; здатність до співробітництва; ініціативність; енергійність); управління емоціями (здібність робити ставку на інших, сенситивність, ідентифікація себе зі справою, здібність до співчуття, зацікавленість в «рості» членів групи, незалежність); особистісний ідеал (гнучкість, стійкість до стресу, наявність цілі, почуття гумору, цілісність особистісного ідеалу) [5].

Необхідно декілька слів сказати і про те, що в ідеалі лідер повинен бути такою людиною, яка притягує увагу оточуючих, має якийсь дивний шарм, вміє впливати на оточуючих. I тут згадаємо про таку загадкову якість, як харизма. Імідж (образ) людини набуває харизматичності тоді, коли в ньому яскраво проявляються його складні глибинні характеристики. Харизматична особистість, зазвичай, викликає сильні ірраціональні переживання у людей. На свідомому рівні вони проявляються як повага, приплив енергії, захоплення, пристрасна прихильність.

Отже, нагадаємо ті із глибинних характеристик іміджу, які є найбільш важливими для лідера [2]:

- близькість, зрозумілість образу (здібність визвати у людини відчуття безпеки, простоти, доступності, зрозумілості і висновку — «свій»);

- енергійність (активність, динамічність, емоційність образу, виразна мова, жива міміка і жести, яскраві ідеї);

- домінантність (сила образу, його впливовість, значущість, здібність викликати бажання прислухатися, здійснювати конкретні дії, змінюватись на краще);

- архетиповість образу (відображення в образі давніх уявлень і імпульсів, наприклад: неабияке значення для авторитету лідера має відповідність його іміджу з архетипами Батька і Матері);

- еталонність, позитивність образу (здібність викликати почуття симпа- тії, довіри, поваги, інтересу, втілення в образі загальнолюдських моральних цінностей і ідеалів).

Ці глибинні якості іміджу здійснюють великий вплив на людей, зокрема, визначають його «ірраціональний магнетизм», чарівність, загадковість, надзвичайність.

Як підкреслюється в відомій теорії харизми М. Вебера, до появи харизматичних лідерів призводить одночасна наявність наступних п'яти чинників: 1) екстраординарної обдарованості; 2) соціальної кризи чи надзвичайної ситуації; 3) наявність ідей по радикальному вирішенню кризи; 4) наявність послідовників, яких приваблює незвичайна особистість і які вірять в те, що лідер напряму пов'язаний 3 трансцендентними силами; 5) підтвердження екстраординарної обдарованості лідера і його трансцендентних можливостей успіхами, які повторюються $[1 ; 2]$. Часто різні автори розглядають харизматичне лідерство як соціологічний феномен, який виникає при взаємодії цих п'яти елементів і стверджують, що для його виникнення необхідна наявність їх всіх в тій чи інший формі.

Досить грунтовну, на наш погляд, інформацію щодо розуміння сутності ефективності лідерської поведінки, надає дослідження Дж. Ландрама, в якому він формулює сім основних секретів талановитого політика і творчого генія. Цей автор проаналізував особливості особистості сорока геніальних людей i зробив спробу відповісти на питання: «Що робить великих людей великими?». Отже, сім секретів: 1) інтуїція; 2) самоповага, впевненість в собі; 3) схильність до ризику; 4) бунтівний дух; 5) одержимість; 6) трудоголізм; 7) наполегливість [6].

Ситуаційна модель лідерства класифікувала лідерів як вмотивованих, головним чином, чи потребою виконувати завдання (які покладаються на лідерів), чи потребою в близьких і довірливих стосунках з членами своєї групи. Ситуація лідерства класифікується як така, яка представляє високу, помірну чи низьку ступінь можливості реалізації лідером влади, впливу, контролю. Ситуаційний контроль визначає, по суті, 
вірогідність того, що лідер зможе добитися виконання завдання, яке на нього покладене. Ситуаційний контроль залежить від того, в який ступені а) група представляється надійною і здійснює свою підтримку, б) завдання структуроване і зрозуміле у відношенні його цілей і методів рішення, в) організація надає даному лідеру власні повноваження - законне право винагороджувати і карати [5].

Ефективність лідерів залежить не тільки від особистості самого лідера, а й від характеристик ситуації лідерства. Вмотивовані завданням лідери досягають найкращого виконання своїх функцій в ситуаціях з високим і низьким ступенем контролю; вмотивовані стосунками лідери досягають найкращого виконання в ситуаціях з помірним ступенем контролю.

Ця ситуаційна модель викликала багаточисельні дискусії. Однак широкий огляд i аналіз емпіричних досліджень, які були присвячені її перевірці, показав достовірність.

Так, в теорії «шлях-ціль» Хауса фокусується увага на взаємодії між поведінкою і ситуацією лідерства. В ній стверджується, що лідер повинен мотивувати підлеглого двома способами: 1) підкреслюючи взаємозв'язок між власними потребами підлеглого і цілями організації; 2) пояснюючи i полегшуючи шлях, який повинен вибрати підлеглий щоб досягнути не тільки вдоволення власних потреб, а й організаційних цілей $[4 ; 5 ; 6]$.

В теорії нормативних рішень ВрумаЙеттона-Яго була запропонована модель, яка описує умови, при яких лідери повинні приймати рішення автократично (після консультацій з членами групи), чи надавати групі повну самостійність у виборі рішення [6].

Останнім часом дослідники проблеми лідерства знову звернулися до вивчення когнітивних процесів, надаючи їм серйозної уваги. Досліджуючи формування оцінок лідерів, Грін і Мітчел знайшли, що лідери виявилися більш критичними до своїх підлеглих, якщо поведінка останніх мала дуже погані наслідки, ніж у випадках коли така ж сама поведінка не мала негативних наслідків. Згідно з ситуаційною теорією Фідлера, ефективність лідера залежить як від його особистісних якостей, так і від ступеню його контролю над ситуацією. На думку дослідників, особистісні характеристики утворюють мотиваційну систему і стосуються того, наскільки позитивно лідер оцінює свого найменш бажаного колегу. Саме ця оцінка $\epsilon$ основною змінною в даній теорії. Основне положення даної теорії: лідерська поведінка є рисою особистості і тому оцінка найменш бажаного колеги залишається відносно незмінною. Тому, практично не має сенсу змінювати стиль лідерської поведінки за допомогою тренінгів чи підвищення кваліфікації. Більш розумнішими буде підбір того лідера, чий стиль буде відповідати ситуації, а не чекати, що людина зміниться і адаптується до цієї ситуації [5].

Треба зауважити, що Фідлер, Поттер, Зейс і Ноултон повторно вивчали роль інтелектуальних здібностей лідера і наявність релевантного досвіду виконавчої діяльності. В серії своїх досліджень вони показали, що науковці зарано скинули з рахунків роль інтелекту і професійних знань і що ці важливі змінні необхідно знов повернути в теорію лідерства.

Ще одним важливим напрямком в цій області стало вивчення впливу ключових характеристик роботи і компонентів завдання на поведінку і ефективність лідера i членів групи [3].

Важливим аспектом проблеми лідерства $\epsilon$ мотивація лідерської поведінки. Як вважає багато вчених, сама природа лідерства означає те, що важливими для нього $€$ такі риси, як комунікабельність, потреби у владі і в досягненнях [4; 6]. Дослідження Кирпатрика і Лока показали, що лідерів від нелідерів відрізняють наступні риси, які характеризують їх мотиваційну сферу: потяги (потреба в досягненнях, честолюбство, енергія, наполегливість, ініціатива); мотивація лідерства (персоніфікована чи соціалізована). Різниця між типами мотивації лідерства — персоніфікованою і соціалізованою - $\epsilon$, на думку цих вчених, 
суттєвою. Так, персоніфікована мотивація лідерства характерна для людей, які прагнуть влади заради іiі самої, бажають домінувати над іншими і часто зацікавлені в статусі і атрибутах влади. А лідери, які мають мотивацію до соціалізованої влади, щоб досягнути бажаних цілей, більше прагнуть до співробітництва 3 іншими (а не до домінування над ними). Зрозуміло, що для підлеглих, учнів і організації в цілому, лідери, які прагнуть до соціалізованої влади, більш корисні [5].

Як вже зазначалось, на думку багатьох вчених, сама природа лідерства обумовлює важливість такої риси, як комунікабельність [4]. А для ефективної діяльності фахівців соціономічних професій особливо необхідним є високий рівень комунікативної компетентності. Варто зазначити, що увага до поняття «компетентність» в останні роки обумовлена не тільки його системнопрактичними функціями в загальній освіті, а й рекомендаціями Ради Європи щодо наближення освіти до замовлень соціуму [8; 7]. Тому в концептуальній модернізації вітчизняної освіти формуванню ключових компетентностей надається велике значення. Зауважимо, що єдиного узгодженого визначення та переліку ключових компетентностей на сьогодні не існує, оскільки компетентності - це насамперед замовлення суспільства на підготовку його громадян. Такий перелік багато в чому визначається узгодженою позицією соціуму в певній країні або регіоні. Зрозуміло, що досягти такого узгодження вдається не завжди.

Перш ніж описати зміст комунікативної компетентності, визначимося 3 дефініцією даного поняття з освітньої точки зору. Часто поняття «компетентність» формулюють через поняття «готовність» учня. Наприклад: «Готовність учня використовувати засвоєні знання, навчальні вміння та навички, а також способи діяльності в житті для рішення практичних і теоретичних задач» [7]. У словнику С. Ожегова під готовністю розуміється «згода зробити що-небудь» або «стан, при якому все зроблено, усе готове для чого-небудь». Але, на думку А. Хуторського, в даному випадку не врахо- вується особистісне значеннєве ставлення учня до майбутньої діяльності, до предмета цієї діяльності, а також не конкретизується, які саме «практичні та теоретичні задачі» будуть вирішуватись при реалізації компетентності [7].

Наступне розповсюджене трактування компенетності спирається поняття здатності: «Компетентність - це загальна здатність, заснована на знаннях, досвіді, цінностях, схильностях, що придбані завдяки навчанню»; «Компетентність - це здатність до здійснення практичних діяльностей, що вимагають наявності понятійної системи й, отже, розуміння, відповідного типу мислення, що дозволяє оперативно вирішувати проблеми та задачі, що виникають» [7]. Зауважимо, що найчастіше здатність в психології розглядається як індивідуально-психологічна особливість особистості, яка є умовою успішного виконання певної діяльності. Але компетентність $€$ не тільки «індивідуально-психологічною особливістю», а й також характеризує певне коло діяльностей (причому не тільки практичних) і певне коло об'єктів (предметів), стосовно яких ця компетентність задається [7; 8]. Таким чином компетентність стає певною загальною якістю, стандартизованою для багатьох індивідів, яка вводиться як загальна норма.

В психологічній літературі разом 3 поняттям «компетентність» часто використовується поняття «компетенція», яку розглядають як відчужену, наперед задану соціальну вимогу (норму) до освітньої підготовки учня, необхідної для його якісної продуктивної діяльності в певній сфері. Змістовна основа компетенції: знання, які повинна мати особа; коло питань, в яких особа повинна бути обізнана; досвід, необхідний для успішного виконання роботи у відповідності з установленими правами, законами, статутом. Всі ці аспекти (знання, коло питань, досвід) подаються як узагальнені поняття, що не стосуються конкретної особи і не є ï особистісною характеристикою.

Отже, компетенція — це певна норма, досягнення якої може свідчити про можли- 
вість правильного вирішення якого-небудь завдання. Відповідно, компетентність - це володіння (оволодіння) учнем відповідною компетенцією, що включає його особистісне ставлення до цієї компетенції та до предмета діяльності [7; 8]. Іншими словами, компетентність - це оцінка досягнення (або недосягнення) цієї норми. Компетентність виступає в українській і російській мовах як якість, характеристика особи, яка дозволяє їй (або навіть дає право) вирішувати певні завдання, виносити рішення, судження у певній галузі. Як вже було сказано, основою цієї якості є знання, обізнаність, досвід соціально-професійної діяльності людини. Але компетентність не зводиться тільки до знань чи тільки вмінь. На думку вчених, компетентність є сферою відносин, що існують між знанням і дією в людській практиці. Тобто, компетентність припускає наявність мінімального досвіду застосування компетенції [7; 8]. Резюмуючи, можемо сказати, що компетентність - це особистісна якість (чи сукупність якостей), що вже відбулась, і мінімальний досвід діяльності в заданій сфері [7].

Компетентність особистості припускає прояв стосовно компетенції цілого спектра особистісних якостей. «Поняття компетентності включає не тільки когнітивну й операціонально-технологічну складові, а й мотиваційну, етичну, соціальну та поведінкову» [7]. Отже, компетентність завжди особистісно забарвлена якостями конкретного учня: від значеннєвих і світоглядних (навіщо мені необхідна дана компетентність) до рефлексивно-оцінних (наскільки успішно я застосовую дану компетентність у житті).

Ключові освітні компетентності (які відносяться до загального метапредметного змісту освіти) конкретизуються на рівні освітніх галузей і навчальних предметів для кожного ступеня навчання. Визначаються ключові освітні компетентності на основі: головних цілей загальної освіти; структурного представлення соціального досвіду й досвіду особистості; основних видів діяльності учня (що дозволяють йому опановувати соціальний досвід, одержувати навички життя та практичної діяльності в сучасному суспільстві) [7].

Комунікативна компетентність (яка $€$ однією із ключових освітніх компетентностей) включає знання різних способів взаємодії з оточуючими (зокрема, знання необхідних мов) людьми та подіями, навички роботи у групі, володіння різними соціальними ролями у колективі. Особистість має вміти презентувати себе, ставити запитання, вести дискусію тощо. Для освоєння даної компетентності, зокрема, в навчальному процесі фіксується необхідна й достатня кількість реальних об'єктів комунікації та способів роботи з ними [7].

Висновки. Таким чином, різні підходи щодо розуміння феномену лідерства, які були розглянуті, дозволяють зробити ряд висновків:

- в сучасному суспільстві різні ситуації вимагають різних рис лідерства і форм поведінки;

- аналіз досліджень за проблемою лідерства дає можливість визначити певні вимоги до соціальної ролі лідера в нашому суспільстві: лідер повинен мати здібність брати керування на себе, бути гнучким в управлінні людьми; лідер повинен визначати і структурувати свою роботу i роботу підлеглих, спрямовану на досягнення загальної цілі (він повинен чітко визначати обов'язки підлеглих і грати активну роль в спрямуванні дій групи через планування, повідомлення інформації, критику чи пропонування нових ідей); лідер повинен вміти створювати в групі консенсус, атмосферу співробітництва, відношень взаємної довірі, поваги, взаєморозуміння, прихильності до однієї ідеї; лідер повинен турбуватися як про людей, так і про рішення завдання; вміти розвинути у членів групи відданість загальній справі і мотивацію до досягнень; залучити людей до сумісної роботи і спонукати ïх робити те, що необхідно організації (групі, команді); стійким до стресу, енергійним і наполегливим; має бути зацікавлений в «рості» членів групи і сам бути завжди на шаг попереду своїх підлеглих, 
приділяти постійну увагу особистісному i професійному росту та відкривати перед

командою нові горизонти перспективних цілей.

\section{Список використаних джерел:}

1. Гоулман Д. Эмоциональное лидерство: Искусство управления людьми на основе эмоционального интеллекта / Дэниел Гоулман, Ричард Бояцис, Энни Макки; Пер. с англ. - М. : Альпина Бизнес Букс, 2005. - 301 с.

2. Змановская Е. В. Руководство по управленню личным имиджем / Е. В. Змановская. СПб. : Речь, 2005. - 144 с.

3. Имидж лидера. Психологическое пособие для политиков. - М. : Общество «Знание» России, 1994.

4. Майерс Д. Социальная психология / Д. Майерс. - СПб. : Питер Ком., 1998. — 688 с.

5. Психология лидерства в бизнесе / В. Шеклтон. - СПб. : Питер, 2003. - 222 с.

6. Психология современного лидерства: Американские исследования. - М. : КогитоЦентр, 2007. - 288 с.

7. Хуторской А. В. Ключевые компетенции как компонент личностно-ориентированной парадигмы образования / А. В. Хуторской // Ученик в общеобразовательной школе. - М. : ИОСО РАО, 2002. - С. 135-157.

8. Шадриков В.Д. Новая модель специалиста: инновационная подготовка и компетентностный подход / В. Д. Шадриков // Высшее образование сегодня. — № 8. — 2004. C. 26-31.

Аннотация. В статье проанализированы современные научные данные, накопленные в области психологии лидерства, с точки зрения влияния этого феномена на успешность деятельности специалистов сочиономических профессий. Лидерство рассматривается как способность вести за собой, руководить или управлять группой/организацией. Показано, что в современном обществе разные ситуации требуют разных качеств лидерства и разных форм поведения. На основе анализа исследований по проблемам лидерства определены определенные требования к соииальной роли лидерства в обществе, в частности: лидер должен иметь способность брать руководство на себя; быть гибким в управлении людьми; уметь создавать в группе консенсус, атмосферу сотрудничества, отношения взаимного доверия, уважения, взаимопонимания, верность одной идее; уметь заботиться и про людей и про решение задачи; быть стойким к стрессу, быть энергичным и настойчивым.

Ключевые слова: лидер, лидерство, модели лидерства, успешность деятельности специалистов социономических профессий, профессиональный опыт, компетентность, коммуникативная компетентность.

Abstracts. In the article was analyzed the modern scientific data which are collected on the area of psychology of the leadership for knowing how this phenomenon influences on the success of specialists of the socionomic profession activity. Leadership is showing as an ability to lead follow, guide or direct of the group lorganization. Was sowed that in the modern world different situations demand different features of leadership and different forms of behavior. On the base of the analysis of the leadership problem investigation was determine some requirements to the role of leader in our society, particularly: leader should have the capability keeps the directing; should be a flexible in the leading of people; should be able to create the consensus, atmosphere of cooperation, trust relationship, respect, mutual understanding, propensity to one idea in group; should be able to take care of both people and about doing task; should be stressful, energy and persistent; should be able to define and structure his own and inferiors work which is aimed at achieving a common goal (leader should defines inferiors responsibilities clearly and should plays active role in the guiding of group activities by the planning, informing, critics, new ideas etc.); leader should be able to develop dedication to the common idea and motivation to the achievements in the members of the group; leader should be able to invite people to the common work and motivate do things which is necessary to all grouplteamlorganization; leader should be able to growth of every member of group and always be on the step ahead, focus on professional and individual growth, open to the team new horizons of long-term goals. Was showed that the communicative competence is includes the knowledge of different modes of interaction with people and developments around, skills of group work, possession of different social roles in the group |team lorganization.

Keywords: leader, leadership, models of leadership, successful professional activity of socionomic professions specialists, professional experience, competence, communicative competence. 